\title{
An Exploratory Role Analysis Of Opinion Leaders, Adopters, And Communicative Adopters With A Dynamically Continuous Innovation
}

\author{
Mary F. Hazeldine, Georgia Southern University, USA
}

Morgan P. Miles, Georgia Southern University, USA \& University of Tasmania, Australia

\begin{abstract}
Since Venkatraman's (1989) research on communicative adopters, little attention has been directed toward this segment of consumers who are often very important actors in the adoption process. This research is designed to examine whether Venkatraman's (1989) communicative adopter concept is applicable to dynamically continuous innovations, in this case, Graphic User Interface (GUI) computer software. The communicative adopter group was found to be significantly different than all other groups on all constructs except homophily. Consistent with Venkatraman's (1989) research, the communicative adopter segment can be called "Change Agents." Each of the three segments, opinion leaders, adopters, and communicative adopters, is important to marketers of new GUI computer software, but this research suggests that the best prospects in terms of marketing efforts are the communicative adopters. The results extend research in this area and provide support for theory development. Issues with respect to managerial implications, such as market segmentation strategies, are also discussed.
\end{abstract}

Keywords: communicative adopters, change agents, dynamically continuous innovations

\section{INTRODUCTION}

\section{Research aim}

This study attempts to complement and extend Venkatraman's (1989) previous research in the area of communicative adopter theory and continuous innovations by examining the relationships between opinion leadership and adoptive behavior for a dynamically continuous innovation. Graphic User Interface (GUI) computer software is the dynamically continuous innovation chosen for study. Examples of GUI software are Microsoft windows or Apple Macintosh software programs, smart phone touch screens, and retail self-service check-out systems which use symbols to reduce operational complexity and increase user efficiency.

Specifically, the research objectives are as follows:

1. To review the consumer opinion leadership, adopter, and communicative adopter literature in relation to dynamically continuous innovations.

2. To construct the scales used in communicative adopter studies for GUI computer software and to evaluate the scale's psychometric properties, such as reliability and factorial validity.

3. To examine the relationship between opinion leadership, adopter behavior and communicative adopter behavior with regard to other constructs identified as relevant by past literature.

4. To present implications for marketing management. 


\section{Reasoning for the focus of the paper}

The process by which new products and ideas are accepted and then diffused throughout a society has received considerable research attention and is emerging as a topic of significant importance in marketing and entrepreneurship (Robertson, 1971; Baumgarten, 1975; Gatignon \& Robertson, 1985; Venkatraman 1989; Goldsmith \& Goldsmith, 1996; Woodside \& Biemans 2005; Shoham \& Ayalla, 2008; Kim, Fiore, Niehm, \& Jeong 2010). This concept, called the Diffusion of Innovations, has been identified by Rogers (1983) as having two major roles for consumers: (1) the innovator or early adopter in the life cycle who is responsible for the initial consumption or application of a new product, and (2) the opinion leader who diffuses product information and usage experiences to his/her reference groups. When these two roles are combined and held by one group of actors these communicative adopters emerge as the market's change agents (Venkatraman's,1989).

The majority of past research on the relationship between adoptive behavior and opinion leadership has examined the diffusion of innovation process with regard to discontinuous product innovations. A discontinuous innovation is a new product that involves the establishment of new consumption patterns and the creation of previously unknown products (Robertson, 1971). This type of innovation would also require significant change in existing attitudes and behaviors on the part of the adopter (Robertson, 1971). For example, the transition of university libraries adopting sophisticated electronic databases composed of search engines and PDFs (such as ABIINFORM) of papers as an Internet-based substitute for the traditional library holdings of hardcopies of books, journals, and manuscripts required dramatic changes in both the attitudes and behaviors of librarians and scholars alike. This type of innovation typically follows the hierarchy of effects, high-involvement model. In this model, the consumer moves through a series of steps, from awareness and information gathering to preference and attitude development, then eventually to an observable behavior, such as trial of the product. A second form of innovation is continuous innovation which is characterized by no major changes in either product type or existing purchasing behavior, and includes the adoption processes that relate to the evolution of different types of memory devices for the PC such as floppy disks, Zip drives, CDs, and now memory sticks.

Robertson (1971) believes that the diffusion of new innovations is not dichotomized into either a continuous or a discontinuous category. Rather, he posits that a continuum exists for classifying new product innovations by how continuous or discontinuous their effects are on established consumption patterns. Consequently, he identifies a mid-level third category of product innovation that is located between the two extremes of this continuum. This category is referred to as a dynamically continuous innovation and is described by Robertson (1971) as an innovation involving the creation of a new product or the alteration of an existing one, but without dramatically altering existing consumption patterns or attitudes. An example of this type of innovation would be the rapid adoption of smart phones that combine the functions of cell phones, with mobile computing, media and entertainment networking capabilities.

Most of the past research has examined the Diffusion of Innovation with respect only to opinion leadership and adoptive behavior characteristics. However, the study by Venkatraman (1989) using a continuous innovation revealed that in movie-going behavior the opinion leader and adopter groups merge to form a third group, called "communicative adopters." Communicative adopters are those who scored high on both the opinion leadership and the adoptive behavior scales. From a marketing management perspective, this group of consumers is important to identify because not only will they be among the first to purchase a particular product category, but theses change agents will also be instrumental in diffusing product-related information and opinions to other potential consumers, and thereby drive market adoption.

\section{Previous research}

This study enhances the theory underlying the communicative adopter segment. The nature of this theory is examined in this literature review, which is divided into three sections: 1) opinion leadership and adoptive behavior, 2) innovative communicators, and 3) communicative adopters. 


\section{Opinion Leadership and Adoptive Behavior}

The psychological characteristics that underlie the constructs of opinion leadership and adoptive behavior vary depending on the perspective from which they are being examined (Venkatraman, 1989). Following the Diffusion of Innovation perspective, opinion leadership is defined as the "degree to which an individual is able informally to influence other individuals' attitudes or overt behaviors in a desired way with relative frequency" (Rogers, 1983, p. 271). Past diffusion research indicates that the characteristics of opinion leaders include interpersonal influence, interconnectedness, and homophily (Rogers, 1983; Venkatraman, 1989). Interpersonal influence refers to the degree to which a person influences other people's opinions about their attitudes and purchasing behavior for a particular product. Interconnectedness means the degree to which respondents are linked to other peer-related groups by interpersonal networks. Homophily refers to the degree to which respondents are similar to each other on certain attributes, such as socioeconomic backgrounds and career aspirations.

Concerning the construct of adoptive behavior, the diffusion perspective defines adopters as people "who are relatively early in adopting an innovation, as compared to other members of the social system" (Rogers, 1983, p. 127). Opinion leaders and adopters are similar in socioeconomic status and in seeking media sources of information. They differ in that adopters are risk seekers and change seekers, whereas opinion leaders conform more to the social system and are more interconnected that adopters (Rogers, 1983). As Venkatraman (1989, p. 54) posits in her movie-going research

"opinion leaders may go to a movie because they believe someone may want their opinion on it or because it may be a topic of conversation at social gatherings. For adopters, on the other hand, the personal motives may be more important; they go to movies simply because they enjoy going to movies or because they have great interest in and knowledge about movies."

From a marketing perspective, opinion leaders are characterized by influence, interpersonal word-of-mouth communication, expertise, and innovative behavior (Myers \& Robertson, 1972; Feick \& Price, 1987; Flynn, Goldsmith, \& Eastman, 1996). It is also believed that opinion leaders have an enduring involvement with a product class, which motivates them to seek and share information with others (Corey, 1971; Bloch \& Richins, 1983; Venkatraman, 1989; Goldsmith \& Flynn, 1994). Therefore, it is relevant to examine opinion leaders in terms of enduring involvement, influence, expertise, and information sharing.

With regard to adopters, consumer behavior literature indicates that they seem to be more innovative than others in their peer group, and they adopt a new innovation more quickly than others to the extent they possess certain situational and consumer characteristics such as a consumer's enduring involvement with the product, the extent of product class use and the socioeconomic status of the consumer (Venkatraman, 1989). Adopters seem to be more endearingly involved with, seek more mass media information about, and more heavily consume a product class than non-adopters (Taylor, 1977; Midgley \& Dowling, 1978; Bloch, Sherrell, \& Ridgway, 1986). Nonadopters are those who diffuse innovations differently than adopters, including opinion leaders. Thus, it is important to compare opinion leaders and adopters in terms of influence, expertise, information sharing, information seeking, frequency of using a particular product, and enduring involvement in the use of a particular product. These comparisons, consequently, will allow the two groups to be identified.

$\underline{\text { Innovative Communicators }}$

Although the traditional marketing perspective on the diffusion of innovations held that only two groups of market actors, opinion leaders and adopters, were responsible for the diffusion of new products (Myers \& Robertson, 1972; Taylor, 1977; Shoham \& Ayalla, 2008), research by Baumgarten (1975), Venkatraman (1989), and Midgley and Dowling (1993) show that a unique third group exists who are high in both opinion leadership and adoptive behavior. This group of market actors is particularly relevant to marketers because they typically diffuse new products more quickly and are usually more easily identified (Venkatraman, 1989). Baumgarten's (1975) work provided an early understanding of these market actors who are both opinion leaders and adopters. Baumgarten (1975) divided his sample into those who were high, medium, or low on opinion leadership and on adoptive behavior. Those who scored high on opinion leadership and high on adoptive behavior were termed "innovative 
communicators." Those scoring high on only the opinion leadership scale or the adopter behavior scale were termed opinion leaders and adopters, respectively, and all the other respondents were classified as "others" (not high on either scale). He found a difference between the "innovative communicators" and the "others" groups on demographics, social activities, mass media exposure, and psychological and sociopolitical attitude factors.

Additional findings on the innovative communicator segment were inconsistent. Hirschman and Adcock (1977) extended Baumgarten's (1975) research by examining the differences among "innovative communicators," opinion leaders, adopters, and "others." They found few meaningful differences between these groups on variables that included demographic, sociographic, and media usage characteristics.

\section{$\underline{\text { Communicative Adopters }}$}

Venkatraman (1989), based on Baumgarten's (1975) and Hirschman et al.'s (1977) work, conducted a cluster analysis of 317 student movie goers that revealed four clusters: (1) opinion leaders (those scoring high on the opinion leadership scale); (2) adopters (those scoring high on the adopter scale); (3) communicative adopters (those scoring high on both opinion leadership and on adoptive behavior scales); and (4) others (subjects scored less than high on either the opinion leader or adopter scales). Venkatraman (1989) used the term "communicative adopters" which Baumgarten (1975) called "innovative communicators" because she believed that it was the adoption status, not the innovativeness of individuals that was being measured. She then examined the difference between these clusters. Based on the diffusion literature, the differences were explained in terms of homophily, interconnectedness, and motives for seeing movies. With regard to the consumer behavior literature the differences were defined in terms of enduring involvement, influence, expertise, and information sharing; with information sharing either in person or online (Sun, Youn, Wu, and Kuntaraporn 2006). Smith and Timpany (1991), in a replication of Venkatraman's (1989) study, also found evidence of the communicative adopter group with regard to movie-going behavior. Also, a working paper by Smith and Timpany (1996) examined personal computer behavior, a discontinuous innovation. Using an adapted version of the scale used by Venkatraman (1989), their work supported Venkatraman (1989) by also identifying a group of market actors (communicative adopters) that scored high on both opinion leadership and adoptive behavior. Subsequently, similar results were found when comparing the adopters, opinion leader, and communicative adopter groups with regard to other relevant diffusion constructs.

The majority of the past communicative adopter research has been conducted using either continuous or discontinuous innovations. That is, no marketing study has compared opinion leaders, adopters, and communicative adopter segments using a dynamically continuous innovation product category. The research question which follows is, therefore, whether the same groups found in the Venkatraman (1989) study can also be identified when using a dynamically continuous product category.

\section{RESEACH AND EPISTEMOLOGICAL APPROACH}

Because this study was a replication and extension, it utilized the survey research design developed by Venkatraman (1989). A cluster analysis was performed using scores on the opinion leadership and adoptive behavior scales, and the independent variable was the diffusion of innovation condition formed by the cluster analysis. The four expected conditions were: opinion leader, adopter, communicative adopter, and other. The dependent measures were the scores on each of the construct subscales: enduring involvement, influence, expertise, information sharing, on-going information seeking, frequency of GUI software use, personal motives for using GUI software, social motives for using GUI computer software, interconnectedness, and homophily. Group comparisons were made for each of the diffusion of innovation conditions (opinion leader, adopter, communicative adopter, and other) across each of the constructs.

\section{$\underline{\text { Sample }}$}

The subjects in previous communicative adopter research were university students. Therefore, the subjects for the present study were 332 students from a west coast state university campus between the ages of 18-50 years. Students in undergraduate marketing classes were given an opportunity to participate in the study as part of the study's non-random convenience sample. The sample size not only approximates the Venkatraman (1989) study (n 
$=329)$, but also meets the recommended number of subjects $(\mathrm{n}>259)$ needed to attain a power level of .80 with a "medium" effect size (Cohen 1977). That is, a sample size of 260 or more will present an 80 percent probability that the communicative adopter group, if it does exist, will be found with a medium effect size.

Selection of the Product Category

Robertson (1971) describes three types of innovations: continuous, dynamically continuous, and discontinuous. The major factor determining under which type of innovation group a particular product category would fall is to what extent established consumption patterns are altered. Specifically, continuous innovations cause little or no disruption of existing behavioral patterns and usually involve the modification of an existing product. Discontinuous innovations, on the other hand, require the establishment of new consumption patterns, consumer attitudes, as well as a new product. Dynamically continuous innovations, then, are products that cause some disruption in existing behavioral patterns, but with forcing dramatic changes in consumer attitudes, and may either be a new product or a modification to an existing one. The introduction of GUI computer software (for example touch screens on smart phones) most certainly leads to a significant change in existing patterns of personal computing behavior. Thus, Graphic User Interface computer software when the data where gathered (mid-1990s) meets the criteria of a dynamically continuous innovation.

Justification of the Product's Innovation Type

Robertson (1971) expanded the traditional dichotomous perspective of innovations. He described new innovations on a theoretical continuum from continuous to discontinuous innovations, with dynamically continuous innovations comprising the area in the middle of the continuum. Before the inception of this continuum, product categories that were neither continuous nor discontinuous innovations were theoretically unaccounted for. Hence, the addition of the dynamically continuous innovation to the diffusion model allows any product category to be placed on the continuum, based on its innovation characteristics.

\section{$\underline{\text { Hypotheses }}$}

This study examined the following hypotheses:

$\mathbf{H}_{1}$ : $\quad$ The opinion leader and the adopter groups will merge to form the communicative adopter group using GUI computer software, a dynamically continuous innovation, as the product category.

$\mathbf{H}_{2}$ : The communicative adopter group will have significantly greater enduring involvement, influence, expertise, on-going information seeking, information sharing, and frequency of product usage than the adopter, opinion leader, or "other" groups.

\section{METHODOLOGY}

This study used a product category that intuitively fits into the theoretical definition of a dynamically continuous innovation. In order to give objective confirmation as to the dynamically continuous status of the chosen product category (GUI computer software), a 12-item scale was constructed. Rogers (1961) described five characteristics of innovations: relative advantage, compatibility, complexity, trial ability, and observability. Fliegel and Kivlin (1966) expanded this list to include factors such as financial cost, social cost, and perceived risk associated with the use of the product. Additional factors regarding understandability, required behavioral change, ease of use, and pre-purchase information seeking were added to the scale.

The scale was administered to 37 undergraduate marketing students, and each respondent was asked to judge 6 product categories, including GUI computer software, on each of these 12 innovation factors. A 5-point Likert scale format (strongly agree $=5$, strongly disagree $=1$ ) was used. The mean scores for each product category and the reliability estimate of the scale can be found in Table 1. 
Table 1

Innovation Questionnaire Mean Scores For Six Product Categories $(N=37)$

\begin{tabular}{lc}
\hline \hline \multicolumn{1}{c}{ Innovation } & Mean Score \\
\hline Toothpaste & 1.97 \\
Movies & 2.38 \\
Restaurants & 2.55 \\
Fashions & 2.59 \\
Graphic User Interface Software & 3.89 \\
Personal Computers & 3.94 \\
Alpha Coefficient. 88 & \\
\hline \hline
\end{tabular}

The means of each of the product categories in Table 1 create a rank order in terms of innovation type, where the products with the lower means are more continuous and the products with higher means are more discontinuous. The rank order established by this scale indicates a similarity to previous descriptions of these products (except GUI computer software) in diffusion research (Venkatraman 1989; Smith \& Timpany, 1996). Specifically, toothpaste, movies, restaurants, and fashions comprise product categories at the continuous end of the theoretical continuum, and these categories become more and more discontinuous in the order listed. Conversely, personal computers have been identified as a discontinuous product (Smith \& Timpany, 1996). The results of this scale places GUI computer software as less continuous than personal computers but more discontinuous than new fashions. The proximity of the GUI software category to the personal computer category is expected because both are computer products. The position of GUI computer software on the theoretical continuum relative to the other products tested, therefore, gives additional evidence that GUI computer software is a dynamically continuous product category.

\section{Measures}

Childers' (1986) version of the King and Summers (1970) scale was used to measure opinion leadership due to its established convergent and discriminant validity properties (Yavas \& Riecken, 1982; Childers, 1986). The remainder of the survey utilized the same items and constructs as those used in Venkatraman's (1989) study of movie-going behavior. These scales have demonstrated strong reliability coefficients and have been shown to have evidence of factorial validity (Smith \& Timpany, 1996). However, due to the nature of differences between movies and graphic user interface computer software, items were reworked to fit GUI computer software usage behavior.

The survey consisted of 10 constructs that are defined in Table 2. Most of these constructs used a 5-point, Likert-type scale, and the survey consisted of 64 items. A series of demographic items was included at the end of the survey.

\section{Scale Construction}

The 64-item scale was based on the 64-item survey measuring the same constructs by Venkatraman (1989). The pretest subjects were 54 undergraduate university marketing students. The scale for opinion leadership formed a unidimensional factor. The items in the adoptive behavior scale did not seem to form a single factor. Item \#11 did not load heavily on either factor and appeared to load on a third, unidentified dimension. Some question existed as to the factorial validity of the adoptive behavior scale when using Item \#11, suggesting that it should be dropped in the analysis.

Cronbach's alpha analyses were performed for each of the subscales. The alphas ranged from 0.80 to 0.93 , implying that the scale is fairly reliable. It should be noted that for the adoptive behavior scale, the alpha coefficient increased from 0.67 to 0.85 with the deletion of Item \#11. This along with its inability to contribute to the scale's factorial validity, gave support to deleting Item \#11 from the study. 
Table 2

Definitions And Citations For The Subscale Constructs Used In The Study

\begin{tabular}{|c|c|c|c|}
\hline Construct & \# Items & 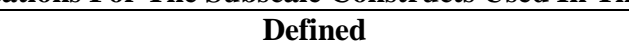 & Citation \\
\hline Opinion Leadership & 7 & $\begin{array}{l}\text { One who diffuses product information and } \\
\text { usage experiences to his/her surrounding peer } \\
\text { group culture. }\end{array}$ & $\begin{array}{l}\text { Childers' (1986) version of } \\
\text { the King and Summers } \\
\text { (1970) scale }\end{array}$ \\
\hline Adoptive Behavior & 4 & $\begin{array}{l}\text { One who is responsible for the initial } \\
\text { consumption or application of a new product. }\end{array}$ & $\begin{array}{l}\text { Midgley and Dowling } \\
(1978)\end{array}$ \\
\hline Enduring Involvement & 10 & On-going concern with a product class. & $\begin{array}{l}\text { Bloch and Richins (1983), } \\
\text { Richins and Bloch (1986) }\end{array}$ \\
\hline Influence & 7 & $\begin{array}{l}\text { The degree to which the respondents influence } \\
\text { other people's opinions about GUI computer } \\
\text { software and their choice of GUI software. }\end{array}$ & Venkatraman (1989) \\
\hline Expertise & 4 & $\begin{array}{l}\text { Subjective prior knowledge or perception of } \\
\text { their knowledge about GUI computer software. }\end{array}$ & Brucks (1985) \\
\hline $\begin{array}{l}\text { On-Going Information } \\
\text { Seeking }\end{array}$ & 4 & $\begin{array}{l}\text { Search activities that occur on a continuous } \\
\text { basis and are independent of specific purchase } \\
\text { needs. }\end{array}$ & $\begin{array}{l}\text { Block, Sherrell, and } \\
\text { Ridgway (1986) }\end{array}$ \\
\hline Information Sharing & 8 & $\begin{array}{l}\text { The extent to which respondents talk to friends } \\
\text { about GUI computer software, discuss and listen } \\
\text { to other people's opinions and share their } \\
\text { opinions with others. }\end{array}$ & Venkatraman (1989) \\
\hline Frequency & 1 & Frequency of using GUI computer software. & Venkatraman (1989) \\
\hline $\begin{array}{l}\text { Personal motives for } \\
\text { using GUI computer } \\
\text { software }\end{array}$ & 5 & $\begin{array}{l}\text { The importance of motives as using GUI } \\
\text { computer software because one enjoys them or } \\
\text { because of a great interest in them. }\end{array}$ & Venkatraman (1989) \\
\hline $\begin{array}{l}\text { Social motives for using } \\
\text { GUI computer software }\end{array}$ & 2 & $\begin{array}{l}\text { The extent to which respondents are involved in } \\
\text { or use GUI computer software because they } \\
\text { believe someone may want their opinion of GUI } \\
\text { computer software or because it may be a topic } \\
\text { of conversation at social gatherings. }\end{array}$ & Venkatraman (1989) \\
\hline Interconnectedness & 4 & $\begin{array}{l}\text { The degree to which respondents are linked to } \\
\text { other students by interpersonal networks. }\end{array}$ & Venkatraman (1989) \\
\hline Homophily & 7 & $\begin{array}{l}\text { The degree to which respondents are similar to } \\
\text { other students on certain attributes such as } \\
\text { socioeconomic backgrounds and career } \\
\text { aspirations. }\end{array}$ & Venkatraman (1989) \\
\hline
\end{tabular}

\section{Procedure}

The participants received a survey and an accompanying informed consent form. The respondents were allowed to complete the survey during class, and the surveys were collected at that time. The respondents were asked to fill out the questionnaires carefully or to not do so at all. The questionnaires were subsequently checked for nonsense answers, data falsification, and systematic responses, and the questionnaires containing suspect data were deleted from the study. Twenty-one cases were determined to contain systematic responses and were removed from the analysis; thus, the sample size for the study was 311.

\section{RESULTS}

Significant positive skewness was revealed in opinion leadership $(z=-3.43, p<.01)$ and significant negative skewness was shown in information sharing $(z=-3.71, p<.01)$, and homophily $(z=3.72, p<.01)$. It was decided not to correct for this skewness because it is believed that the skewness is a representation of a true nonnormal distribution of these constructs in the population rather than measurement error inherent in the survey. 


\section{Factorial Validity}

A factor analysis was performed on each of the subscales for the data set. A summary of the factor analysis can be seen in Table 3. Each loads heavily on one factor. Two unique factors emerged: (1) opinion leadership, and (2) adoptive behavior. The opinion leadership sub-scale account for 44.80 percent of variance, while the adopter sub-scale accounts for 10.40 percent of variance.

Table 3

Factor Analysis Of The Opinion Leadership And Adoptive Behavior Subscales Using Oblique Rotation (N=332)

\begin{tabular}{|c|c|c|c|c|c|}
\hline \multirow[t]{2}{*}{ Construct } & \multirow[t]{2}{*}{ Item \# } & \multirow[t]{2}{*}{ Mean } & \multirow[t]{2}{*}{ S.D. } & \multicolumn{2}{|c|}{ Factor Loadings } \\
\hline & & & & $\mathbf{I}$ & $\mathbf{I i}$ \\
\hline \multirow[t]{7}{*}{ Opinion Leadership } & 1 & 2.32 & 1.15 & $\underline{.85}$ & .05 \\
\hline & 2 & 2.11 & 1.12 & .78 & -.07 \\
\hline & 3 & 1.92 & 1.17 & .78 & -.05 \\
\hline & 4 & 2.24 & 1.19 &. .69 & -.07 \\
\hline & 5 & 2.53 & 1.41 & .32 & .01 \\
\hline & 6 & 2.26 & 1.21 &. .68 & .05 \\
\hline & 7 & 2.66 & 1.27 & .56 & .01 \\
\hline \multirow[t]{3}{*}{ Adoptive Behavior } & 8 & 2.45 & 1.05 & -.07 & $\underline{.85}$ \\
\hline & 9 & 2.45 & 1.12 & .15 &.$\overline{.76}$ \\
\hline & 10 & 2.26 & 1.09 & .01 & .89 \\
\hline Eigenvalues & & & & 4.48 & 1.04 \\
\hline \% Variance Explained & & & & 44.80 & 10.40 \\
\hline
\end{tabular}

\section{Reliability}

Cronbach's alpha statistics were calculated to estimate the reliability of each of the multi-item scales used in this study (Table 4). The alpha coefficients, which ranged from .77 to .92 , gave evidence of strong reliability for the other subscales. In addition, the reliability of the scales compared favorably and were consistent with the reliability metrics reported by Venkatraman (1989).

Table 4

Constructs, Number Of Items, And Alpha Coefficients ( $N=332$ )

\begin{tabular}{|c|c|c|c|c|}
\hline \multirow[b]{2}{*}{ Construct } & \multicolumn{2}{|c|}{ Number of Items } & \multicolumn{2}{|c|}{ Coefficient Alpha } \\
\hline & This Study & Venkatraman & This Study & Venkatraman \\
\hline \multicolumn{5}{|l|}{ Groups } \\
\hline$\overline{\text { Opinion Leadership }}$ & 7 & 7 & 0.83 & 0.77 \\
\hline Adoptive Behavior & 3 & 4 & 0.88 & 0.71 \\
\hline \multicolumn{5}{|c|}{ Opinion Leader And Adopter Characteristics } \\
\hline Enduring Involvement & 10 & 10 & 0.92 & 0.80 \\
\hline Influence & 7 & 6 & 0.90 & 0.76 \\
\hline Expertise & 4 & 5 & 0.86 & 0.76 \\
\hline On-Going Information Seeking & 4 & 4 & 0.89 & 0.70 \\
\hline Information Sharing & 8 & 8 & 0.91 & 0.71 \\
\hline Frequency of GUI Software Use & 1 & 1 & -- & -- \\
\hline \multicolumn{5}{|c|}{ Motives For Using Gui Computer Software } \\
\hline Personal & 5 & 5 & 0.81 & 0.66 \\
\hline Social & 2 & 2 & 0.77 & 0.69 \\
\hline \multicolumn{5}{|l|}{ Indicator Of Network Behavior } \\
\hline Homophily & 7 & 7 & 0.82 & 0.74 \\
\hline
\end{tabular}




\section{Identification of Clusters}

The correlation between the opinion leadership and the adoptive behavior scales is .52 in this study and .30 in Venkatraman's study. Both findings are consistent with previous research (Robertson \& Myers, 1969; Myers \& Robertson, 1972). The number of clusters used in this study was determined by past opinion leadership research by Venkatraman (1989), which used the Calinski and Harabasz index (Milligan \& Cooper, 1985) to identify the number of naturally occurring clusters within her sample. The solution with the highest index in the Venkatraman study (1989) was four clusters.

It was hypothesized (H1) that the opinion leadership and the adoptive behavior groups would merge as a result of the cluster analysis procedure to form the communicative adopter group. The mean opinion leadership and adoptive behavior scores for all four groups can be found in Table 5. As can be seen from the table, the formation of the communicative adopter group did occur as hypothesized. That is, the mean communicative adopter scores are the highest scores of all four groups in each of the two clustering subscales; thus support was found for H1. The communicative adopter scores for the opinion leadership and adoptive behavior scales were 4.07 and 3.80, respectively.

Table 5

Cluster Means Of The Four Groups $(\mathrm{N}=332)$

\begin{tabular}{lcccccc}
\hline \hline & \multicolumn{3}{c}{ GUI Computer Software } & & \multicolumn{2}{c}{ Movie Going } \\
\cline { 3 - 7 } Group & $\boldsymbol{n}$ & $\begin{array}{c}\text { Opinion } \\
\text { Leadership }\end{array}$ & $\begin{array}{c}\text { Adoptive } \\
\text { Behavior }\end{array}$ & $\boldsymbol{n}$ & $\begin{array}{c}\text { Opinion } \\
\text { Leadership }\end{array}$ & $\begin{array}{c}\text { Adoptive } \\
\text { Behavior }\end{array}$ \\
\hline Communicative Adopters & 39 & 4.07 & 3.80 & 71 & 4.09 & 3.66 \\
Opinion Leaders & 69 & 2.98 & 2.85 & 84 & 3.76 & 2.04 \\
Adopters & 119 & 2.11 & 2.22 & 129 & 3.08 & 2.83 \\
Others & 108 & 1.33 & 1.80 & 33 & 2.32 & 1.95 \\
\hline \hline
\end{tabular}

The other three groups formed in a manner that was also consistent with the Venkatraman (1989) study. Next to the communicative adopter group, the second highest opinion leader score was assigned to the opinion leader group. The second highest adoptive behavior score was given to the adopter group. The opinion leader cluster had mean scores of 2.98 on the opinion leadership scale and 2.85 on the adoptive behavior scale. The adopter group had scores of 2.11 and 2.22 on the opinion leadership and adoptive behavior scales, respectively. Lastly, the cluster with the lowest scores on both scales was termed "others."

\section{Differences among Groups}

It was hypothesized that significant differences would exist between communicative adopters and opinion leaders, adopters, and "others," with regard to enduring involvement, influence expertise, on-going information seeking, information sharing, frequency of using GUI computer software, personal motives, and social motives. For each of the dependent variables, a separate one way analysis of variance with Scheffé post hoc comparisons was used to test the four cluster means for differences. The results of the analysis of variances and the post hoc comparisons can be found in Table 6 .

As hypothesized (H2), Scheffé post hoc comparisons of the analyses of variances revealed significant differences between the communicative adopter group and the opinion leader, adopter, and "other" groups on enduring involvement, influence, expertise, on-going information seeking, information sharing, personal motives, and social motives; thus $\mathrm{H} 2$ was supported. The strength of the effect sizes $\left(\omega^{2}\right)$ for the ANOVAs should also be noted. According to Kirk (1995), a $\omega^{2}$ statistic of at least .138 indicates a strong effect size. As can be seen in Table 6 , the $\omega^{2}$ values range from .36 to .59 , which far exceed Kirk's recommended cut point for a strong effect size. Group differences with regard to homophily, however, were not significant, $F(3,328)=.22, p<.87$.

Communicative adopters seem to be more interconnected than any of the other groups. Of the communicative adopters, 41.6 percent of them attended more than 15 social functions within the last year, compared 
to 29.8 percent of adopters, 20.6 percent of opinion leaders, and 19.8 percent of the "others" $\left(\chi^{2}=8.67\right)$. Communicative adopters also seemed to be more involved with fraternities and sororities. Of the communicative adopters, 27.8 percent of them belonged to a fraternity or sorority, whereas 13.6 percent, 13.2 percent, and 5.7 percent of the adopters, opinion leaders, and "others," respectively, were members of one of these organizations $\left(\chi^{2}=\right.$ 12.37). Lastly, 77.8 percent of the communicative adopters belonged to organizations other than a fraternity or sorority. For adopters, 50.4 percent were members or other organizations, and 48.5 percent of opinion leaders and 36.8 percent of "others" belonged to other organizations $\left(\chi^{2}=18.34\right)$

Table 6

Analysis Of Variance And Post Hoc Comparisons Of The Four Diffusion Segments On Key Opinion Leader And Adopter Characteristics $(N=332)$

\begin{tabular}{|c|c|c|c|c|c|c|}
\hline Characteristic & $\begin{array}{l}\text { Comm. } \\
\text { Adopters } \\
\text { Mean } \\
\text { (sd) }\end{array}$ & $\begin{array}{c}\text { Opinion } \\
\text { Leaders } \\
\text { Mean } \\
\text { (sd) }\end{array}$ & $\begin{array}{c}\text { Adopters } \\
\text { Mean } \\
\text { (sd) }\end{array}$ & $\begin{array}{c}\text { Others } \\
\text { Mean } \\
\text { (sd) }\end{array}$ & $\begin{array}{c}\text { F-Value* } \\
{\left[\omega^{2}\right]}\end{array}$ & $\begin{array}{c}\text { Significant } \\
\text { Scheffé } \\
\text { Post Hocs }\end{array}$ \\
\hline & (1) & (2) & (3) & (4) & & \\
\hline $\begin{array}{l}\text { Enduring } \\
\text { Involvement }\end{array}$ & $\begin{array}{l}3.88 \\
(.55)\end{array}$ & $\begin{array}{l}3.01 \\
(.49)\end{array}$ & $\begin{array}{l}2.35 \\
(.62)\end{array}$ & $\begin{array}{l}1.88 \\
(.66)\end{array}$ & $\begin{array}{c}121.40 \\
{[.59]}\end{array}$ & $\begin{array}{c}1: 2,3,4 \\
2: 3,4 \\
3: 4\end{array}$ \\
\hline Influence & $\begin{array}{l}3.88 \\
(.44)\end{array}$ & $\begin{array}{l}3.08 \\
(.54)\end{array}$ & $\begin{array}{l}2.44 \\
(.64)\end{array}$ & $\begin{array}{l}1.94 \\
(.72)\end{array}$ & $\begin{array}{c}105.21 \\
{[.55]}\end{array}$ & $\begin{array}{c}1: 2,3,4 \\
2: 3,4 \\
3: 4\end{array}$ \\
\hline Expertise & $\begin{array}{l}3.72 \\
(.63)\end{array}$ & $\begin{array}{l}2.79 \\
(.68)\end{array}$ & $\begin{array}{l}2.21 \\
(.65)\end{array}$ & $\begin{array}{l}1.72 \\
(.77)\end{array}$ & $\begin{array}{l}87.53 \\
{[.51]}\end{array}$ & $\begin{array}{c}1: 2,3,4 \\
2: 3,4 \\
3: 4\end{array}$ \\
\hline $\begin{array}{l}\text { On-Going } \\
\text { Information Seeking }\end{array}$ & $\begin{array}{l}3.88 \\
(.62)\end{array}$ & $\begin{array}{l}2.84 \\
(.78)\end{array}$ & $\begin{array}{l}2.29 \\
(.69)\end{array}$ & $\begin{array}{l}1.87 \\
(.74)\end{array}$ & $\begin{array}{c}73.24 \\
{[.46]}\end{array}$ & $\begin{array}{c}1: 2,3,4 \\
2: 3,4 \\
3: 4\end{array}$ \\
\hline Information Sharing & $\begin{array}{l}3.70 \\
(.48)\end{array}$ & $\begin{array}{l}3.34 \\
(.56)\end{array}$ & $\begin{array}{l}2.86 \\
(.75)\end{array}$ & $\begin{array}{l}2.26 \\
(.85)\end{array}$ & $\begin{array}{l}50.00 \\
{[.36]}\end{array}$ & $\begin{array}{c}1: 3,4 \\
2: 3,4 \\
3: 4\end{array}$ \\
\hline $\begin{array}{l}\text { GUI Use Frequency } \\
\text { (Days per week) }\end{array}$ & $\begin{array}{c}5.72 \\
(1.77)\end{array}$ & $\begin{array}{c}3.66 \\
(1.71)\end{array}$ & $\begin{array}{c}2.23 \\
(1.78)\end{array}$ & $\begin{array}{c}1.11 \\
(1.32)\end{array}$ & $\begin{array}{l}86.01 \\
{[.50]}\end{array}$ & $\begin{array}{c}1: 2,3,4 \\
2: 3,4 \\
3: 4\end{array}$ \\
\hline Personal & $\begin{array}{l}4.17 \\
(.46)\end{array}$ & $\begin{array}{l}3.54 \\
(.46)\end{array}$ & $\begin{array}{l}3.17 \\
(.61)\end{array}$ & $\begin{array}{l}2.71 \\
(.70)\end{array}$ & $\begin{array}{l}63.10 \\
{[.42]}\end{array}$ & $\begin{array}{c}1: 2,3,4 \\
2: 3,4 \\
3: 4\end{array}$ \\
\hline Social & $\begin{array}{l}4.00 \\
(.56)\end{array}$ & $\begin{array}{l}3.31 \\
(.56)\end{array}$ & $\begin{array}{l}2.78 \\
(.65)\end{array}$ & $\begin{array}{l}2.19 \\
(.85)\end{array}$ & $\begin{array}{l}74.88 \\
{[.47]}\end{array}$ & $\begin{array}{c}1: 2,3,4 \\
2: 3,4 \\
3: 4\end{array}$ \\
\hline
\end{tabular}

*All $\mathrm{F}$ statistics are significant at $\mathrm{p}<.0001$.

\section{CONCLUSION}

The findings of this study are limited due to both the non-random nature of the sampling frame and the use of only one product to represent dynamically continuous innovations. These findings should not be generalized across other samples or products. However, as an exploratory study the results may be used to direct future research to better understand the role of communicative adopters in the diffusion of dynamically continuous innovations. 
It was hypothesized that the opinion leader and adopter groups would merge to form the communicative adopter group and that this segment would have significantly different scores on key opinion leadership and adoptive behavior characteristics. The results of the cluster analysis support this hypothesis in that the communicative adopter group was identified as those having the highest opinion leadership and adoptive behavior scores, and these findings are consistent with past research (Venkatraman 1989; Smith \& Timpany, 1996). Additional support for the hypothesis is given because the communicative adopter segment had higher enduring involvement and influence with GUI computer software than did the other segments. The communicative adopter segment also sought and shared information and acquired greater expertise about GUI computer software than did the other groups.

The superiority of the communicative adopter segment relative to other actor groups can be identified in diffusion of innovations terms that this segment is more socially interconnected and more influential to others about the dynamically continuous innovation (GUI software) than are opinion leaders and adopters. Communicative adopters also tend to use more GUI computer software and are more motivated (for both social and personal reasons) to use GUI software than the other segments. Also, they tend to be more interconnected with their peers than the other segments. Therefore, not only do communicative adopters use the innovation more frequently than others, but they also influence other people through interpersonal communication. Consistent with Venkatraman's (1989) research, the communicative adopter segment can be called the market's "Change Agents."

\section{Communicative Adopter Theory}

The present study extends communicative adopter theory in that it serves to explore diffusion behavior by suggesting a unique innovation type not previously considered in past diffusion research. The innovation type, a dynamically continuous innovation, was represented by the GUI software product category. The dynamically continuous innovation is relevant to explore in terms of communicative adopter theory because past research has considered only continuous and discontinuous innovations. Previous innovation models have treated the type of innovation as a dichotomous continuum, whereas continuous innovations occupied one end of the continuum and discontinuous innovations were located at the other end. This study, therefore, gives evidence for a more complete diffusion of innovation model, which places the dynamically continuous innovation segment on the continuum between the two other innovation types. However, additional research is needed to add strength to the theory. Alternative product categories representing each of the innovation types should be tested to determine whether the presence of the communicative adopter segment is stable across other products and industries.

\section{Managerial Implications}

To the extent that the findings are limited, the results may offer tentative managerial implications on the role of communicative adopters in the diffusion of dynamically continuous innovations. Each of the three segments, opinion leaders, adopters, and communicative adopters, is important to marketers of dynamically continuous innovations, but this research suggests that potentially communicative adopters are the best prospects for marketers of dynamically continuously innovations. In the merging of the adopter and opinion leadership groups, the communicative adopters are identified as a segment of consumers that are not only sought out for information about the innovation, but are among the first to try the innovation. Therefore, communicative adopters may be perceived to be generally more influential in the overall diffusion process of dynamically continuous innovations, such as GUI software, and may prove to be the most effective segment for which to target with advertising and promotional campaigns. Hence, communicative adopters may be the best prospects targeting when a marketer is introducing a new product or modified product that fits within the dynamically continuous innovations rubric.

The thorough understanding of this unique marketing segment should be the aim of entrepreneurs and organizations who wish to have their products or services rapidly diffused throughout their target market. One of the ways to maximize our understanding of communicative adopters is to identify this segment's media usage habits. Given the communicative adopter's prolific information-gathering behavior, efforts to understand the nature of this behavior in terms of their preferred media vehicles followed by an appropriate promotional strategy should prove beneficial. In addition, information about communicative adopters concerning attitudes, interests, and opinions as well as psychographic data should help marketers focus their resources in the most effective mediums. Knowledge 
of frequency of product use, social interconnectedness, and values and life-style characteristics should also be considered. Future research, using a random sample and multiple products as examples of dynamically continuous innovations, may be able to provide a more complete perspective of these very important phenomena in marketing research.

\section{AUTHOR INFORMATION}

Mary F. Hazeldine is a Professor of Marketing at Georgia Southern University. She received her BS and MA degrees from Oklahoma State University and her MBA and PhD from The University of Texas at Arlington. She came to GSU in 1995 as Chair of the Department of Marketing. In 2006 was appointed as Associate Dean of the College of Business Administration. Dr. Hazeldine is a member of the Rotary Club of Downtown Statesboro and served as the club's Secretary from 2003 to 2006. She is currently an Assistant Governor for Rotary District 6920. Her research interests are in the areas of buyer behavior, entrepreneurship, and business strategy.

Morgan P. Miles is holds a D.B.A. in Marketing from Mississippi State University. His research interests include the interface between marketing, ethics, and corporate entrepreneurship. He has been a Senior Research Associate for the Judge Institute of Management, Cambridge University, a visiting Professor at the University of Stockholm, the University of Otago, Massey University, and University of Auckland.

\section{REFERENCES}

1. Baumgarten, S.A. (1975). The Innovative Communicator in the Diffusion Process. Journal of Marketing Research, 2, 12-18.

2. Bloch, P.H. \& Richins, M.L. (1983). A Theoretical Model for the Study of Consumer Importance Perceptions. Journal of Marketing, 47, 69-81.

3. Bloch, P.H., Sherrell, D.L. \& Ridgway, N.M. (1986). Consumer Search: An Extended Framework. Journal of Consumer Research, 13, 119-126.

4. Brucks, M. (1985). The Effects of Product Class Knowledge on Information Search Behavior. Journal of Consumer Research, 13, 1-16.

5. Childers, T. L. (1986). Assessment of the Psychometric Properties of an Opinion Leadership Scale. Journal of Marketing Research, 23, 184-187.

6. Cohen, J. (1977), Statistical Power Analysis for the Behavioral Sciences, New York: Academic Press.

7. Corey, L.G. (1971). People Who Claim to be Opinion Leaders: Identifying Their Characteristics by Self Report. Journal of Marketing, 35, 48-53.

8. Feick, L.F. \& Price, L.L. (1987). The Market Maven: A Diffuser of Marketplace Information. Journal of Marketing, 51, 83-98.

9. Fliegel, F.C. \& Kivlin, J.E. (1966). Attributes of Innovations as Factors in Diffusion. American Journal of Sociology, 72, 235-248.

10. Flynn, L.R., Goldsmith, R.E., \& Eastman, J.K. (1996). Opinion Leaders and Opinion Seekers: Two New measurement Scales. Journal of the Academy of Marketing Science, 24, 137-147.

11. Gatignon, H. \& Robertson, T.S. (1985). A Propositional Inventory for New Diffusion Research. Journal of Consumer Research, 11, 849-867.

12. Goldsmith, R.E. \& Goldsmith, E,B. (1996). An Empirical Study of Overlap of Innovativeness. Psychological Reports, 79, 1113-1114.

13. Goldsmith, R.E. \& Flynn, L.R. (1993-1994). Opinion Leadership for Vacation Travel Services. Advances in Business Studies, 4, 17-29.

14. Hirschman, E.C. \& Adcock, W.O. (1977). An Examination of Innovative Communicators, Opinion Leaders and Innovators for Men's Fashion Apparel. in Advances in Consumer Research, Ann Arbor: Association for Consumer Research, 849-867.

15. Kim, H., Fiore, A., Niehm, L. \& Jeong, M. (2010). Psychographic characteristics affecting behavioral intentions towards pop-up retail. International Journal of Retail \& Distribution Management, 38, 2, 133 154.

16. King, C.W., \& Summers, J.O. (1970). Overlap of Opinion Leadership Across Consumer Product Categories. Journal of Marketing Research, 7, 43-50. 
17. $\quad$ Kirk, R. E. (1995), Experimental Design, Grove, CA.: Brooks/Cole, p. 178.

18. Midgley, D.F. \& Dowling, G.R. (1978). Innovativeness: The Concept and Its Measurement. Journal of Consumer Research, 4, 229-242.

19. Midgley, D.F. \& Dowling, G.R. (1993). A Longitudinal Study of Product Form Innovation: The Interaction between Predispositions and Social Messages. Journal of Consumer Research, 19, 611-625.

20. Milligan, G.W. \& Cooper, M.C. (1985). An Examination of the Procedures for Determining the Number of Clusters in a Data Set. Psychometrika, 50, 159-179.

21. Myers, J.H. \& Robertson, T.S. (1972). Dimensions of Opinion Leadership. Journal of Marketing Research, 9, 41-46.

22. Richins, M.L. \& Bloch, P.H. (1986). After the New Wears Off: The Temporal Contest of Product Involvement. Journal of Consumer Research, 13, 280-285.

23. Robertson, T.S. (1971). Innovative Behavior and Communications, New York: Holt, Rinehart and Winston.

24. Robertson, T.S. \& Myers, J.H. (1969). Personality Correlates of Opinion Leadership and Innovative Buying Behavior. Journal of Marketing Research, 6, 164-168.

25. Rogers, E.M. (1961). Characteristics of Agricultural Innovators and Other Adopters. Wooster, Ohio: Agricultural Experiment Station Research Bulletin 882.

26. Rogers, E.M. (1983), Diffusion of Innovations, New York: Free Press, 18, 20, 271, 284, 290.

27. Shoham, A. \& Ayalla, R. (2008). Opinion Leaders and Followers: A Replication and Extension, Psychology and Marketing, 25, 280-297.

28. Smith, M.F. \& Timpany, G.A. (1991). Replication of Venkatraman's Role Analysis of Opinion Leaders, Adopters, and Communicative Adopters: Movie Going Behavior. in Retailing: Reflections, Insights and Forecasts, Richmond: The Academy of Marketing/The American Collegiate Retailing Association Special Conference Series, 5, 49-54.

29. Smith, M.F. \& Timpany, G.A. (1996). Role Analysis of Opinion Leaders, Adopters, and Communicative Adopters: Personal Computer Behavior. Working paper, Department of Marketing, Georgia Southern University.

30. Sun, T., Youn, S., Wu, G., and Kuntaraporn, M. (2006). Online word-of-mouth (or mouse): An exploration of its antecedents and consequences. Journal of Computer-Mediated Communication, 11(4), article 11. Available at: $\mathrm{http}: / / \mathrm{jcmc}$. indiana.edu/vol11/issue4/sun.html

31. Taylor, J.W. (1977). A Striking Characteristic of Innovators. Journal of Marketing Research, 14, 104-107.

32. Venkatraman, M.P. (1989). Opinion Leaders, Adopters, and Communicative Adopters: A Role Analysis. Psychology and Marketing, 6, 51-69.

33. Woodside, A. and Biemans, W. (2005). Modeling innovation, manufacturing, diffusion and adoption/rejection processes. Journal of Business \& Industrial Marketing, 20, 7, 380-393.

34. Yavas, U. \& Riecken, G. (1982). Extensions of King and Summers' Opinion Leadership Scale: A Reliability Study. Journal of Marketing Research, 19, 154-155. 


\section{NOTES}

